https://doi.org/10.15407/frg2020.03.224

UDC 632.954: 632.51

\title{
THE EFFICIENCY OF ADJUVANT AGNS 1056-X JOINT APPLICATION WITH HERBICIDES ARYLOXYPHENOXY PROPIONIC ACID DERIVATIVES
}

\author{
Ye.Yu. MORDERER ${ }^{1}$, Zh.Z. GURALCHUK ${ }^{1}$, O.P. RODZEVYCH ${ }^{1}$, L. NOVAK ${ }^{2}$ \\ ${ }^{1}$ Institute of Plant Physiology and Genetics, National Academy of Sciences of Ukraine, \\ 31/17 Vasylkivska Str., 03022 Kyiv, Ukraine, \\ e-mail: morderer@ifrg.kiev.ua \\ ${ }^{2}$ Agrinova Consulting, s.r.o. \\ Za Rybnikem 68325242 Jesenice, Czech Republic \\ e-mail: ludek.novak@agrinova.cz
}

The efficiency of adjuvant AGNS 1056-X joint application with herbicide formulations from a group of graminicides Fusilade Forte and Agil, the active substances of which are aryloxyphenoxy propionic acid (AOPPA) derivatives, was investigated in pot and field experiments. In pot experiment winter wheat (Triticum aestivum L.) plants were used as a model of annual grass weeds. To determine the effect of moisture on the phytotoxic effect of graminicides, in pot experiment artificial drought was created by stopping plants watering. In field experiments, the efficiency of certain grass weed species control, in particular yellow foxtail (Setaria glauca (L.) Pal. Beauv.) and barnyardgrass (Echinochloa crus-galli (L.) Pal. Beauv.), was determined. Estimation of fresh or dry weigth of plants aboveground part and in some experiments the total content of chlorophyll in the leaves was used for evaluation of the phytotoxic effects of herbicides or the efficiency of weeds control. Studies have shown that the addition of adjuvant AGNS 1056-X accelerates the development of the phytotoxic effect of graminicides Fusilade Forte and Agil. The development of graminicides phytotoxic effect accelerated more by addition of adjuvant AGNS 1056-X in drought conditions when grass weeds were in a state of water stress. Although in some cases, joint application with adjuvant AGNS $1056-X$ led to increase of grass weeds control by graminicides, the addition of the adjuvant does not guarantee increased protection efficiency. In this regard, the joint use of graminicides with adjuvant AGNS 1056-X does not allow to reduce the rate of graminicides. To achieve high crop protection efficiency, the graminicides rate should be chosen taking into account the level of weed infestation, stage of weed development and environmental conditions, regardless of whether or not graminicides will be used in conjunction with the adjuvant.

Key words: herbicides, graminicides, adjuvants, phytotoxic action, weed control, drought.

Effective crop protection against weeds is an important prerequisite for consistently high yields. Last years due to the dominance of cereal crops in crop rotations in all soil and climatic zones of Ukraine and, consequently,

Citation: Morderer Ye.Yu., Guralchuk Zh.Z., Rodzevych O.P., Novak L. The efficiency of adjuvant AGNS 1056-X joint application with herbicides aryloxyphenoxy propionic acid derivatives. Fiziol. rast. genet., 2020, 52, No. 3, pp. $224-237$. https://doi.org/10.15407/frg2020.03.224 
due to systematic application of herbicides for dicotyledonous weeds control there is a tendency to increase of crop infestation by grass weeds [1]. The global climate changes, which cause the gradual shift from south to north the boundaries of natural and climatic zones characterized by the dominance of grass weeds [2], is a second factor contributing to the increased infestation of crops by these weeds.

The acetyl-CoA-carboxylase (ACC) inhibiting herbicides widely use for grass weeds control in different dicotyledonous crops. These herbicides affect only grasses and are selective for plants from all other families, due to the characteristics of ACC in the plastids of plants from Poaceae/Gramineae family. In this regard, these herbicides are combined into a group of so-called graminicides. The graminicides includes herbicide formulations, the active ingredients of which belong to two classes of chemical compounds: aryloxyphenoxypropionic acid (AOPPA) derivatives and cyclohexanedione. Herbicide formulations based on both classes of these substances have a relatively low content of active ingredients, from 5 to $25 \%$, and accordingly, the formulation of these herbicides includes a significant number of auxiliary substances, the composition of which is the producers know-how. The difference of the formulations based on AOPPA derivatives from cyclohexanedione is that the latter usually need join application with adjuvants, whereas AOPPA derivatives, which are esters of this acid, usually do not require additional use of adjuvants.

The joint use of herbicides with adjuvants that reduce the surface tension of the working solution, increase the humidity of the leaves during spraying and thereby contribute to the uptake of active ingredients of herbicides into plants, is a fairly common method of increasing the efficiency of weed control by herbicides [3-6]. Recently, innovative multicomponent adjuvants have emerged in the market, which are complex compositions of various surfactants and special co-formulants (moisturizers, emulsifiers, etc.) [7]. In particular, there is the information on the efficacy of adjuvant AGNS 1056-X addition to different herbicides, including AOPPA derivatives graminicides [8]. AGNS $1056-\mathrm{X}$ is a soluble formulation for use as a wetting and spreading agent with approved plant protection products. AGNS 1056-X also contains $\mathrm{pH}$ buffer and water conditioners and is specifically formulated to improve the performance of plant protection products affected by hard water or susceptible to alkaline hydrolysis.

Graminicides are one of the most effective groups of modern herbicides, however, the possibility of increasing the efficiency of their application is certainly worth considering. One of the factors that makes it necessary to find ways to improve the efficiency of graminicides is the dependence of their phytotoxic effects on environmental conditions. In particular, from the very beginning of the introduction of graminicides into practice, it had been found that their phytotoxic effects on grass weeds are substantially reduced in drought conditions [9, 10]. An increase in the activity of the antioxidant protection system caused by the adaptive response of plants to the stressor impact, which in this case is drought, has been found to be a factor in increasing the resistance of weeds to the action of graminicides [11]. Since this reaction is nonspecific, it is possible to overcome the loss of phytotoxic effects on weeds by increasing the rate of 
herbicide application. However, this path is undesirable for both economic and environmental reasons. Considering the fact that global climate changes has led to a sharp increase in the probability of droughts during the crop sowing period [12], it is of considerable interest to increase the efficiency of grass weeds control by adding an adjuvant to the graminicides working solution. Primarily this concerns the graminicides on the base of AOPPA derivatives, since in the known to us scientific literature there are no evidence on the efficiency of adjuvants joint application with these herbicides.

Thus, the aim of this investigation is to study the efficacy, in particular in drought conditions, of adjuvant AGNS 1056-X adding to the AOPPA derivatives herbicides.

\section{Materials and methods}

As far as the efficiency of adjuvant addition may vary diametrically depending on the features of herbicide formulations [13-15], two different herbicide formulations Fusilade Forte 150 EC, e.c. (emulsion concentrate) (fluazifop-P-butyl, $150 \mathrm{~g} / \mathrm{l}$ ) and Agil, e.c. (propaquizafop, $100 \mathrm{~g} / \mathrm{l}$ ), the active ingredients of which belong to AOPPA derivatives, were selected for studying.

Green house and field experiments were conducted for three years in 2017-2019. In the green house experiments winter wheat (Triticum aestivum L.) plants were used as an object as a model of annual grass weeds. The choice of winter wheat plants as an object was also due to the fact that in many cases dicotyledonous crops are infested with self-sown wheat, which is their forecrop.

In the green house experiments winter wheat plants were grown in plastic pots $(1 \mathrm{~kg}$ of soil) with 16 pots in each variant. Herbicide treatment was carried out by spraying the plants at the stage of second leaf $(\mathrm{BBCH} 12)$ with a fixed volume of studied herbicides solution alone or by adding adjuvant AGNS 1056-X in the rate $0.251 /$ ha.

To study the effects of drought on the phytotoxic action of herbicides, soil moisture in some pots was maintained at $60 \%$ field capacity (FC) (optimal moisture conditions) and in other pots at $40 \%$ FC (drought) by cessation of watering. Spraying of plants by herbicides was carried out on the second day after cessation of watering.

Field experiments were carried out in winter oilseed rape, mustard and sunflower crops on the fields of experimental agricultural farm of the Institute of Plant Physiology and Genetics of National Academy of Sciences of Ukraine (Glevakha village, Vasylkiv district, Kyiv region). The area of the experimental plot was $15 \mathrm{~m}^{2}(3 \mathrm{~m} \times 5 \mathrm{~m})$, the experiments were arranged using a randomized complete block design with four replicates. Herbicides were applied by continuous treatment using a backpack sprayer with compressed air $(4 \mathrm{kPa})$, the bar width of $3 \mathrm{~m}$, a number of nozzles -6 , a distance to the target object $-0.5 \mathrm{~m}$, the speed of movement $-5 \mathrm{~km} / \mathrm{h}$, the flow rate of the working solution $-300 \mathrm{l} / \mathrm{ha}$.

The inhibitory effects of herbicides or the effectiveness of weeds control was determided by the reduction of fresh or dry weight of the above- 
ground part of treated plants, and in some experiments by the reduction of total chlorophyll content in the leaves of plants, in comparison with the untreated plants, and calculated in percentage using the following formula:

$$
\mathrm{E}(\%)=100-\left(100 \cdot \mathrm{M}_{\mathrm{i}} / \mathrm{M}_{\mathrm{k}}\right)
$$

where $\mathrm{E}(\%)$ is an inhibitory effect of herbicides or the effectiveness of a certain species of weeds control, $\mathrm{M}_{\mathrm{i}}$ is the the average fresh or dry weight of one plant, or chlorophyll content in the leaves, in the herbicide-treated variant, $M_{k}$ is the value of the corresponding criterion in the untreated variant.

The determination of photosynthetic pigment content in plant leaves was performed by the Welburn method [15]. Chlorophyll content was calculated per unit of fresh weigth.

To determine the fresh and dry weight of plants and the chlorophyll content in the leaves in the pot experiments, each sampling was performed in 4 replications: above-ground part of plants was cut away from 4 pots in each variant of the experiment. In field experiments, plants from 4 counting areas of $0.25 \mathrm{~m}^{2}$ from each plot were cut off.

Statistical analysis of the results was performed by analysis of variance using a standard Microsoft Excel computer package.

\section{Results and discussion}

Influence of the adjuvant AGNS 1056-X on the inhibition of wheat plants fresh matter accumulation by graminicides Fusilade Forte and Agil depending on herbicide application rates was studied in the pot experiment.

As can be seen from Fig. 1, the addition of adjuvant AGNS 1056-X increased the Fusilade Forte inhibitory effect on the accumulation of wheat plants fresh matter under all rates of the herbicide application. At the same

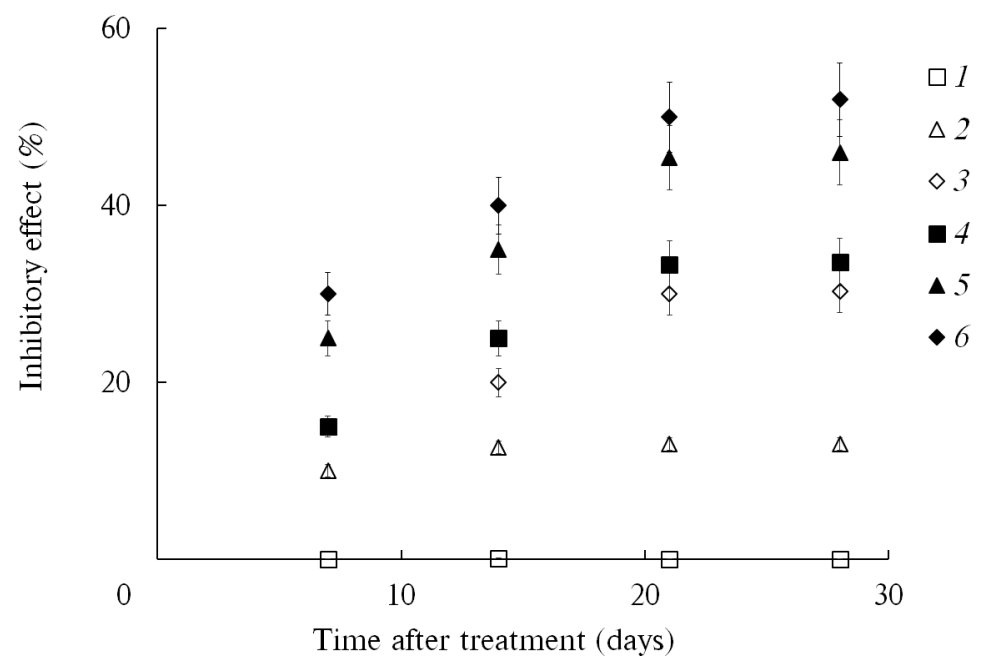

Fig. 1. Inhibitory effect $(\%)$ of herbicide Fusilade Forte with the addition of adjuvant AGNS $1056-\mathrm{X}$ on the winter wheat plants fresh weight accumulation (grass weed model) in 7, 14, 21 and 28 days after treatment:

1-3 - Fusilade Forte $(0.2,0.4,0.5$ 1/ha); 4-6 - Fusilade Forte $(0.2,0.4,0.5$ 1/ha $)+$ AGNS 1056-X $(0.25 \mathrm{l} / \mathrm{ha})$ 
time, the increase of inhibitory effect at application rates of herbicide 0.2 and $0.3 \mathrm{l} / \mathrm{ha}$ was greater than at the maximum rate of $0.5 \mathrm{l} / \mathrm{ha}$. Thus, Fusilade Forte at the minimum application rate of 0.2 1/ha practically did not affect the growth of wheat plants, but with the addition of the adjuvant, the inhibitory effect at 28 days after treatment increased to $33 \%$. In combined application with the adjuvant the inhibitory effect of Fusilade Forte at the rate of $0.2 \mathrm{l} / \mathrm{ha}$ did not differed significantly from the action of herbicide applied alone at the maximum application rate of $0.51 / \mathrm{ha}$. At the same time, with the Fusilade Forte application rate of $0.51 /$ ha, adjuvant addition increased the inhibitory effect only by $22 \%$.

The phytotoxic effect of Agil on wheat plants growth was greater than that of Fusilade Forte (Fig. 2). While at the rate of application of 0.2 1/ha Fusilade Forte practically did not affect the growth of wheat, Agil at the same rate slightly, but significantly suppressed the plants growth. The inhibitory effect of Fusilade Forte alone at $0.5 \mathrm{l}$ /ha reached a maximum of $30 \%$ at 21 days after treatment and did not increase to 28th day. While, Agil's effect at rates exceeding $0.21 /$ ha continued to increase after 21 days and to 28th day reached levels of 42,52 and $65 \%$ at the application rate of $0.3 \mathrm{l} / \mathrm{ha}, 0.4 \mathrm{l} / \mathrm{ha}$ and $0.5 \mathrm{l} / \mathrm{ha}$, respectively. The addition of adjuvant AGNS 1056-X increased the value of Agil inhibitory activity at all rates of application during the entire observation period. The greater effect from the addition of adjuvant observed at lower rates of Agil application, similar to Fusilade Forte. Thus, on the 28th day after treatment with the addition of adjuvant, the inhibitory effect at the application rates of Agil 0.2 1/ha, $0.3 \mathrm{l} / \mathrm{ha}, 0.4 \mathrm{l} / \mathrm{ha}$ and $0.5 \mathrm{l} / \mathrm{ha}$ increased by $46,29,24$ and $15 \%$ respectively.

Summarizing the data, we can conclude that the addition of adjuvant AGNS 1056-X enhanced the effect of graminicide Fusilade Forte at application rates from 0.2 to $0.5 \mathrm{l} / \mathrm{ha}$. The same conclusion can be drawn

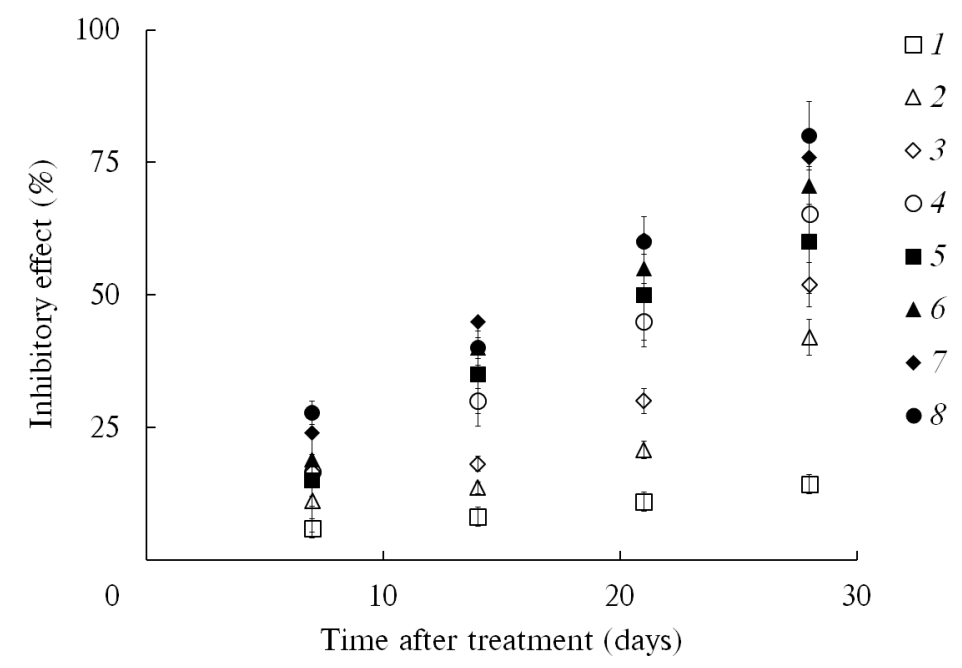

Fig. 2. Inhibitory effect (\%) of herbicide Agil with the addition of adjuvant AGNS 1056-X on the winter wheat plants fresh weight accumulation (grass weed model) in 7, 14, 21 and 28 days after treatment:

1-4 - Agil (0.2;0.3;0.4;0.5 1/ha); 5-8 - Agil (0.2;0.3;0.4;0.5 1/ha) + AGNS 1056-X (0.25 1/ha) 
regarding the effect of adjuvant AGNS 1056-X adding to graminicide Agil at the rate of $0.2 \mathrm{l} / \mathrm{ha}$. At the same time, since unlike Fusilade Forte, the effect of Agil at application rates from 0.3 to $0.5 \mathrm{l} / \mathrm{ha}$ during the period from 21 to 28 days after treatment did not reach saturation and continued to increase. So it can be stated only that the addition of adjuvant AGNS 1056-X accelerated the development of the phytotoxic action of Agil at application rates from 0.3 to $0.5 \mathrm{l} / \mathrm{ha}$.

In drought conditions, the dry weight of plants was used in addition to fresh weight to correctly determine the phytotoxic effect of herbicides, as the change in the water supply level may affect the water content of the plants. To evaluate the rate of development of phytotoxic action the effect of herbicides on the chlorophyll content in the leaves of wheat was also determined.

On the 9th day after treatment by herbicides and, accordingly, on the 11th day after the cessation of watering, the fresh and dry weight of the above-ground part of untreated plants with reduced moisture supply was, respectively, $28 \%$ and $13 \%$ lower than that of the untreated plants with the optimum moisture supply level. On the contrary, the total chlorophyll content in untreated plants at $40 \%$ of $\mathrm{FC}$ was by $31 \%$ higher than the chlorophyll content in untreated plants at $60 \%$ of FC. These data indicate that the drought was moderate and the decrease in moisture supply did not lead to losses in the total chlorophyll content, and inhibition of the dry mass accumulation caused an increase of specific pigments content. At the same time, the influence of herbicides led to a significant decrease in the chlorophyll content in the leaves of plants. In this case, drought conditions significantly reduced the phytotoxic action of Agil herbicide, while the Fusilade Forte inhibitory effect at $40 \%$ FC was not significantly different from its effect at $60 \%$ FC. The addition of adjuvant AGNS 1056-X significantly increased the inhibition of chlorophyll accumulation in wheat leaves by both herbicides at both optimal and reduced moisture levels (Fig. 3).

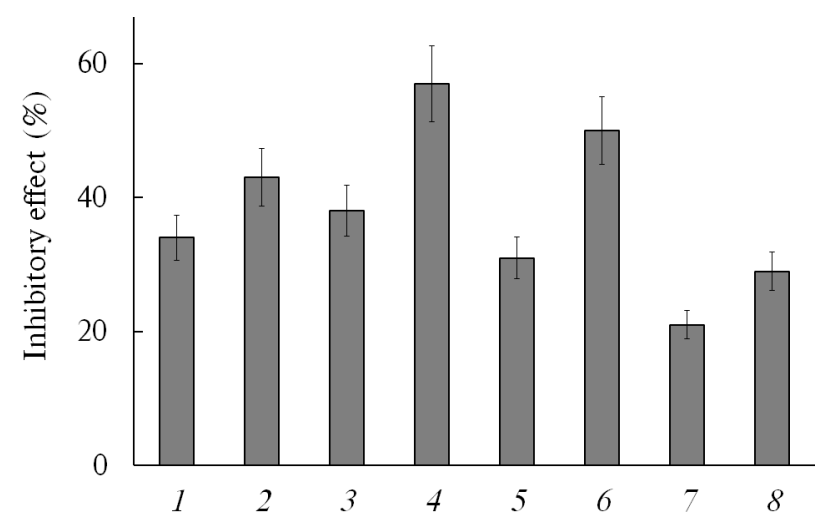

Fig. 3. Inhibitory effect $(\%)$ of herbicides Fusilade Forte and Agil with the addition of adjuvant AGNS 1056-X on the chlorophyll accumulation in the leaves of winter wheat plants (grass weed model) depending on soil moisture levels ( 9 days after treatment):

1, 5 - Fusilade Forte $(0.51 /$ ha); 2, 6 - Fusilade Forte $(0.51 /$ ha $)+$ AGNS 1056-X (0.25 1/ha); 3, 7 Agil (0.4 1/ha); 4, 8- Agil (0.4 1/ha) + AGNS 1056-X (0.25 1/ha); 1-4-60\% FC; 5-8-40\% FC 


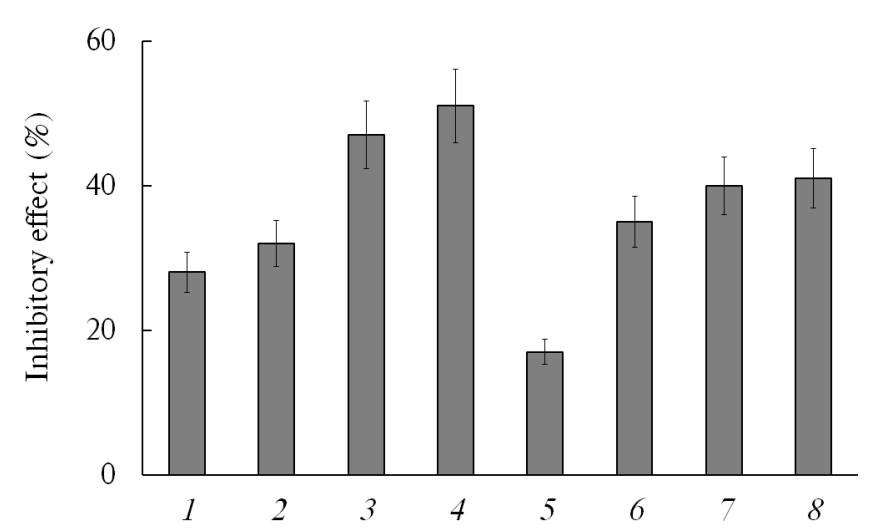

Fig. 4. Inhibitory effect (\%) of herbicides Fusilade Forte and Agil with the addition of adjuvant AGNS 1056-X on the winter wheat plants fresh weight accumulation (grass weed model) depending on the soil moisture levels (14 days after treatment):

1, 5 - Fusilade Forte $(0.51 /$ ha $) ; 2,6$ - Fusilade Forte $(0.51 /$ ha $)+$ AGNS 1056-X (0.25 1/ha); 3, 7 Agil (0.4 1/ha); 4, 8 - Agil (0.4 1/ha) + AGNS 1056-X (0.25 1/ha); 1-4-60\% FC; 5-8- $40 \%$ FC

At 14 days after treatment, the inhibitory effect of Fusilade Forte on the fresh mass accumulation of wheat plants at $40 \%$ FC was significantly less than at $60 \%$ FC (Fig. 4). Agil's effect by this criterion also tended to decrease in drought conditions, but did not differ significantly from its effect under optimal water supply. The addition of adjuvant AGNS 1056-X did not significantly affect the inhibitory effect of Fusilade Forte at $60 \%$ FC, but significantly increased it at $40 \%$ FC. The inhibitory effect of Agil on the wheat plants fresh mass accumulation at both moisture levels did not change with the addition of adjuvant AGNS 1056-X.

The evaluation of phytotoxic action of herbicides by plant dry mass accumulation has yielded somewhat different results. The effect of Fusilade Forte practically did not differ at both levels of moisture supply, and the effect of Agil significantly decreased in drought conditions (Fig. 5). The addition of adjuvant AGNS 1056-X did not affect the inhibition of wheat

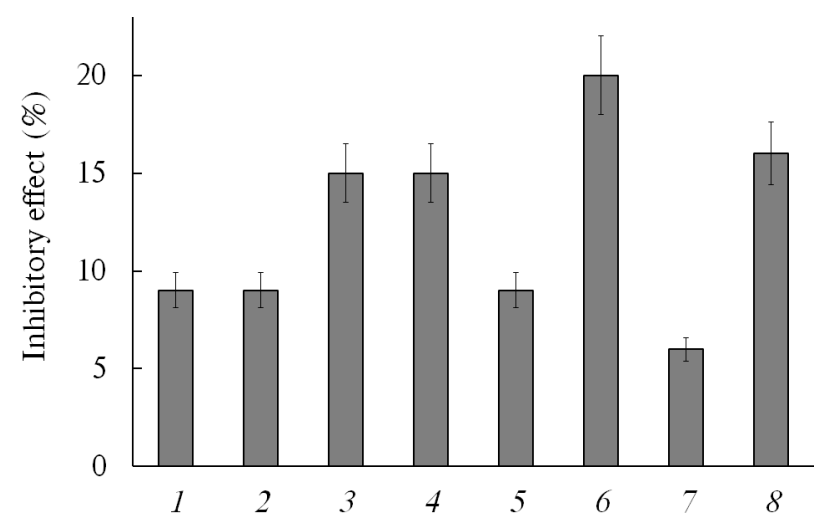

Fig. 5. Inhibitory effect (\%) of herbicides Fusilade Forte and Agil with the addition of adjuvant AGNS 1056-X on the dry weight accumulation of winter wheat plants (grass weed model) (14 days after treatment):

1, 5 - Fusilade Forte $(0.5$ 1/ha); 2, 6 - Fusilade Forte (0.5 1/ha) + AGNS 1056-X (0.25 1/ha); 3, 7 Agil (0.4 1/ha); 4, 8 - Agil (0.4 1/ha) + AGNS 1056-X (0.25 1/ha); 1-4-60\% FC; 5-8- $40 \%$ FC 
TABLE 1. Mustard crops infestation by certain grass weed species and stage of their development at the time of herbicides application

\begin{tabular}{l|c|c|c}
\hline \multicolumn{1}{c|}{ Weed species } & $\begin{array}{c}\text { Number } \\
\text { (specimens/m²) }\end{array}$ & $\begin{array}{c}\text { Stage of develop- } \\
\text { ment (BBCH) }\end{array}$ & $\begin{array}{c}\text { Plant height } \\
(\mathrm{cm})\end{array}$ \\
\hline $\begin{array}{l}\text { Yellow foxtail (Setaria glauca } \text { (L.) } \\
\text { Pal. Beauv.) }\end{array}$ & $14-22$ & 30 & $8-10$ \\
$\begin{array}{l}\text { Barnyard grass (Echinochloa crus- } \\
\text { galli (L.) Pal. Beauv.) }\end{array}$ & $16-20$ & 5 & $10-12$ \\
\hline
\end{tabular}

plants dry mass accumulation by both herbicides under optimal moisture supply, but when the moisture content of the soil was reduced to $40 \% \mathrm{FC}$, the inhibitory effect of both graminicides increased by more than twice when adjuvant was added.

The differences in the effect of moisture supply on the impact of herbicides Fusilade Forte and Agil are probably associated with differences in the speed of the development of their phytotoxic action. Perhaps Fusilade Forte primarily caused moisture loss in plants at the early stages of phytotoxicity and had little effect on the growth of wheat plants, while Agil already suppressed the growth processes in plants at the same time. Therefore, at the background of a significant decrease in the water level of the untreated plants caused by the cessation of soil watering, the inhibitory effect of Fusilade Forte on the fresh mass accumulation was significantly reduced.

At the same time the absence of Fusilade Forte significant influence on the growth processes caused that the stress response of plants to drought, which can reduce the phytotoxic effect of graminicides [11], had no significant effect on impact of Fusilade Forte on inhibition of chlorophyll and dry mass accumulation, which characterize the rate of growth processes. On the other hand, the Agil's impact on these indices was significantly reduced in drought conditions.

However, the data, obtained in pot experiments, indicates that the addition of adjuvant AGNS 1056-X accelerates the development of the both herbicides phytotoxic action. Of particular importance is the fact, that in drought conditions the addition of adjuvant increased the inhibitory effect of Fusilade Forte and Agil on the chlorophyll and dry mass accumulation, since these indices are the most reliable criteria for evaluating the phytotoxic effects of herbicides. Thus, the data obtained are evidence of the feasibility of adjuvant AGNS 1056-X using to accelerate the development of phytotoxic action and prevent the loss of efficacy of graminicides in drought conditions.

In the field experiment in the crops of white mustard (Sinapis alba L.) the control of grass weeds by Fusilade Forte and Agil at rates of 0.5 and 0.4 1/ha, respectively, was determined with the addition of adjuvant AGNS $1056-\mathrm{X}$ at the rate $0.25 \mathrm{l} / \mathrm{ha}$. Herbicide treatment was carried out on 17.05.2018, when the mustard plants were in the phase of stem elongation. At the time of treatment, there was a variable cloudiness, air temperature $20{ }^{\circ} \mathrm{C}$, wind $3 \mathrm{~m} / \mathrm{s}$. The nature of weed infestation of the crops at the time of treatment is given in Table 1 .

Determination of the total chlorophyll content in the leaves of the yellow foxtail plants at 7th day after treatment of mustard crop by graminicides showed that the addition of adjuvant AGNS 1056-X significantly 


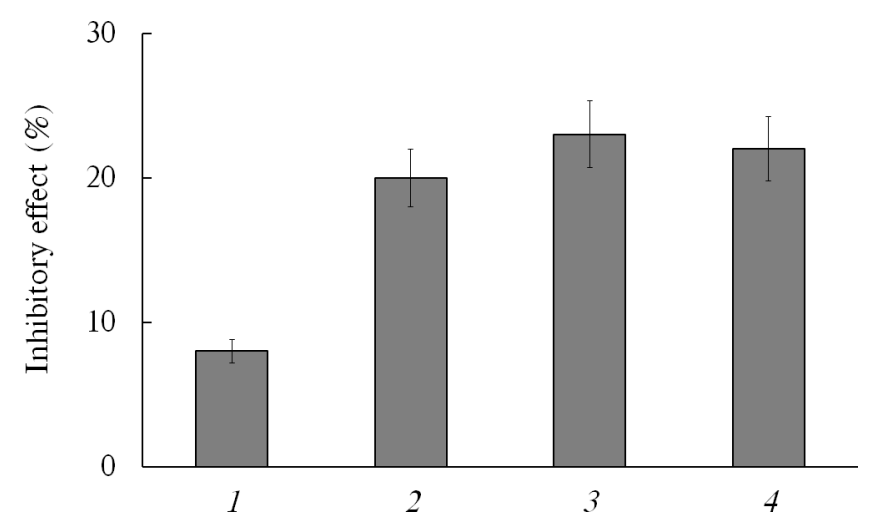

Fig. 6. Inhibitory effect (\%) of herbicides Fusilade Forte and Agil with the addition of adjuvant AGNS 1056-X on the chlorophyll accumulation in the leaves of yellow foxtail in 7 days after treatment of mustard crops:

1 - Fusilade Forte $(0.5 \mathrm{l} / \mathrm{ha}) ; 2$ - Fusilade Forte $(0.5 \mathrm{l} / \mathrm{ha})+$ AGNS 1056-X $(0.25 \mathrm{l} / \mathrm{ha}) ; 3$ - Agil (0.4 1/ha); 4 - Agil (0.4 1/ha) + AGNS 1056-X (0.25 1/ha)

accelerated the development of the phytotoxic action of Fusilade Forte and practically did not affect Agil's action (Fig. 6).

Determination of weed control efficacy at 28th day after treatment showed that barnyard grass was more sensitive to Fusilade Forte action than yellow foxtail, and yellow foxtail control by Agil exceeded Fusilade Forte effect (Table 2). Despite the fact that at 7th day after treatment, the addition of adjuvant AGNS 1056-X accelerated the development of Fusilade Forte phytotoxic action on yellow foxtail (Fig. 6), at the 28th day after treatment, there was no significant difference in the efficiency of this weed control by Fusilade Forte alone and with the adjuvant. Adding of adjuvant also did not affect the efficiency of both weeds species control by Agil (Table 2).

The pot experiment has shown that the greatest effect of adjuvant addition is achieved with lower rates of herbicide application. However, in the field experiment at the time of treatment a significant part of grass weeds had reached the tillering phase so the use of Fusilade Forte and Agil at rates less than the minimum recommended made no sense. To test the expediency of adjuvant AGNS 1056-X use with graminicides at the minimum recommended rates of application, an experiment was carried out in winter rapeseed crops, infested by self-sown winter wheat. The treatment

TABLE 2. The efficacy (\%) of yellow foxtail and barnyardgrass control in 28 days after treatment of mustard crops by herbicides Fusilade Forte and Agil with the addition of adjuvant AGNS 1056-X

\begin{tabular}{c|c|c|c}
\hline № & Treatment & Yellow foxtail & Barnyardgrass \\
\hline 1 & Fusilade Forte (0.5 1/ha) & 58 & 74 \\
2 & Fusilade Forte (0.5 1/ha) + AGNS 1056-X (0.25 1/ha) & 64 & 78 \\
3 & Agil (0.4 1/ha) & 81 & 86 \\
4 & Agil (0.4 l/ha) + AGNS 1056-X (0.25 1/ha) & 86 & 89 \\
& LSD $_{05}$ & 10 & 8 \\
\hline
\end{tabular}


TABLE 3. The efficacy (\%) of self-sown winter wheat control in 15 and 30 days after treatment (DAT) of winter oilseed rape crops by herbicides Fusilade Forte and Agil with the addition of adjuvant AGNS 1056-X

\begin{tabular}{|c|c|c|c|}
\hline № & Treatment & 15 DAT & 30 DAT \\
\hline 1 & Fusilade Forte $(0.5$ l/ha $)$ & 40 & 81 \\
\hline 2 & Fusilade Forte $(0.5$ l/ha $)+$ AGNS 1056-X $(0.25$ l/ha $)$ & 53 & 80 \\
\hline 3 & Agil (0.4 1/ha) & 53 & 84 \\
\hline \multirow[t]{2}{*}{4} & Agil (0.4 1/ha) + AGNS 1056-X (0.25 1/ha) & 58 & 86 \\
\hline & $\operatorname{LSD}_{05}$ & 10 & 8 \\
\hline
\end{tabular}

of crops with herbicides was carried out on 01.10 .2018 , when the rapeseed plants reached the phase of 2-4 leaves. At the time of the treatment there was sunny weather, air temperature $13{ }^{\circ} \mathrm{C}$, wind $3 \mathrm{~m} / \mathrm{s}$. The winter wheat plants reached the phase of 3 leaves and a height of $8-10 \mathrm{~cm}$, the degree of weed infestation was 10 specimens $/ \mathrm{m}^{2}$.

The efficacy of self-sown winter wheat control by graminicides is shown in (Table 3). At 15th day after treatment the addition of adjuvant AGNS 1056-X did not affect the action of Agil, but accelerated the development of the phytotoxic action of Fusilade Forte. However, 30 days after treatment, significant difference did not observed in the efficiency of selfsown winter wheat control between variants using herbicides alone and with adjuvant. Perhaps the absence of a positive effect of adjuvant in this experiment is associated with high efficiency of self-sown winter wheat control by both herbicides.

It should be noted, that during both of these field experiments crops spraying was carried out shortly after considerable rainfall. The results of the pot experiment showed that the efficiency of the adjuvant addition to graminicides depends on the state of the plants and increases in drought conditions. It can be concluded that the absence of significant effect of adjuvant AGNS 1056-X on the effectiveness of both graminicides in the field experiments was due to the weather conditions. In order to conclude on the efficacy of adjuvant AGNS 1056-X joint use with graminicides, it is necessary to carry out crop treatment at a time when weed plants will be exposed to water stress.

In this regard, the following field experiments were carried out in sunflower crops during the summer, which was characterized by long periods of drought. On sunflower (Karamba hybrid, soybean forecrop) after sowing, prior to emergence of seedlings, herbicide Primextra was applied. Due to the drying of the topsoil, the efficiency of the grass weeds control by herbicide Primextra has proven to be very low. The treatment by Fusilade Forte and Agil with the addition of adjuvant AGNS 1056-X was carried out on 08.07.2018, when the sunflower plants reached the asterisk phase (BBCH 51). At this time, the grass weeds reached significant sizes, so the rate of Fusilade Forte and Agil was increased, respectively, to 1.0 and $0.8 \mathrm{l} / \mathrm{ha}$. At the time of treatment there was sunny weather, air temperature $20{ }^{\circ} \mathrm{C}$, wind $2 \mathrm{~m} / \mathrm{s}$. The nature of the sunflower sowing infestation is given in Table 4 .

The beginning of summer 2018 was characterized by prolonged periods of drought and high temperatures. Therefore, there is every reason to 
TABLE 4. Infestation of sunflower crops by grass weed species and stage of their development at the time of herbicides application

\begin{tabular}{l|c|c|c}
\hline \multicolumn{1}{c|}{ Weed species } & $\begin{array}{c}\text { Number } \\
(\text { specimens/m²) }\end{array}$ & $\begin{array}{c}\text { Stage of development } \\
(\mathrm{BBCH})\end{array}$ & $\begin{array}{c}\text { Plant height } \\
(\mathrm{cm})\end{array}$ \\
\hline $\begin{array}{l}\text { Yellow foxtail (Setaria glauca }(\mathrm{L} .) \\
\text { Pal. Beauv.) }\end{array}$ & $22-24$ & 10 & $20-30$ \\
$\begin{array}{l}\text { Barnyard grass (Echinochloa crus-galli } \\
\text { (L.) Pal. Beauv.) }\end{array}$ & $24-26$ & 5 & $15-25$ \\
\hline
\end{tabular}

TABLE 5. The efficacy (\%) of yellow foxtail and barnyard grass control in 18 days after sunflower crops treatment by herbicides Fusilade Forte and Agil with the addition of adjuvant AGNS 1056-X

\begin{tabular}{c|c|c|c}
\hline № & Treatment & Yellow foxtail & Barnyard grass \\
\hline 1 & Fusilade Forte (1.0 l/ha) & 53 & 61 \\
2 & Fusilade Forte (1.0 1/ha) + AGNS 1056-X (0.25 l/ha) & 68 & 83 \\
3 & Agil (0.8 1/ha) & 58 & 70 \\
4 & Agil (0.8 l/ha) + AGNS 1056-X (0.25 l/ha) & 76 & 85 \\
& LSD $_{05}$ & 11 & 9 \\
\hline
\end{tabular}

believe that weed plants were in a state of water stress at the time of graminicide treatment. Under high air temperature, the phytotoxic action of graminicides developed quite rapidly and by the 18th day after treatment, a considerable necrosis of the leaves was observed. The efficacy of herbicide application are shown in Table 5. The efficacy of barnyard grass control by both graminicides was higher than that of yellow foxtail, and Agil's action was slightly higher than that of Fusilade Forte. The addition of adjuvant AGNS 1056-X significantly increased the efficacy of the barnyard grass and the more resistant yellow foxtail control by both graminicides.

In order to verify the obtained results, a second experiment with the same herbicide application rates was made in the sunflower crops at the summer of 2019. Treatment was carried out on 13.06.2019, when the sunflower plants were at the stage of $4-6$ leaves. At the time of treatment there was a variable cloudiness $(50 \%)$, air temperature $25^{\circ} \mathrm{C}$, wind $2 \mathrm{~m} / \mathrm{s}$. The sunflower crop was infested mainly by the yellow foxtail (30 specimens $/ \mathrm{m}^{2}$ ). Up to half of the yellow foxtail plants were at the stage of 4 leaves $(\mathrm{BBCH} 14)$, the others were at the tillering stage $(\mathrm{BBCH} 22)$, the height of the plants ranged from 8 to $15 \mathrm{~cm}$. Barnyard grass was found only in some areas, so it was impossible to properly assess the effects of herbicides on this weed species.

At 7th day after treatment the both graminicides impact led to the significant decrease of total chlorophyll content in the leaves of yellow foxtail plants. Under the action of Fusilade Forte and Agil applied alone the inhibitory effects on chlorophyll accumulation were, respectively, $35 \%$ and $46 \%$. The addition of adjuvant significantly increased the inhibitory effect of both herbicides by more than $10 \%$. Thus, we can conclude that the addition of adjuvant AGNS 1056-X accelerated the development of phytotoxic action of both graminicides on yellow foxtail. 


\begin{tabular}{|c|c|c|c|}
\hline № & Treatment & 7 DAT & 28 DAT \\
\hline 1 & Fusilade Forte (1.0 l/ha) & 53 & 63 \\
\hline 2 & Fusilade Forte $(1.01 / \mathrm{ha})+$ AGNS 1056-X $(0.25$ l/ha $)$ & 61 & 64 \\
\hline 3 & Agil (0.8 1/ha) & 65 & 84 \\
\hline \multirow[t]{2}{*}{4} & Agil (0.8 1/ha) + AGNS 1056-X (0.25 l/ha) & 69 & 89 \\
\hline & $\operatorname{LSD}_{05}$ & 10 & 8 \\
\hline
\end{tabular}

Determination of the efficacy of yellow foxtail control by herbicides, judging by suppressing in the plants fresh weight accumulation, showed that at 7th day after treatment the efficiency of yellow foxtail control by Agil is slightly (by $12 \%$ ), but significantly higher than the effect of Fusilade Forte, coinciding with the results obtained when determining the content of chlorophyll. At 28th day after treatment, the efficacy of Fusilade Forte increased slightly, and Agil's activity increased significantly, which confirms Agil's greater efficacy compared to Fusilade Forte, which also coincides with data on the influence of herbicides on chlorophyll content. However, in contrast to the previous experiment, no significant difference was observed between the efficacy of yellow foxtail control when herbicides were applied alone or with adjuvant AGNS 1056-X (Table 6).

Summarizing the results of the conducted pot and field experiments we can draw the following conclusions. The addition of adjuvant AGNS 1056-X accelerates the development of phytotoxic action of graminicides Fusilade Forte and Agil belonging to the group of AOPPA derivatives. The most significant acceleration in the development of the phytotoxic action of graminicides by the addition of adjuvant AGNS 1056-X was observed under drought conditions when grass weeds were in a state of water stress. Although, in some cases joint application with adjuvant AGNS 1056-X led to increase of grass weeds control by graminicides, the addition of the adjuvant does not guarantee increased protection efficiency. In this regard, the joint use of graminicides with adjuvant AGNS 1056-X does not allow to reduce the rate of graminicides application. To achieve high crop protection efficiency, the graminicides rate should be chosen taking into account the level of weed infestation, stage of weed development and environmental conditions, regardless of whether or not graminicides will be used in conjunction with the adjuvant.

\section{REFERENCES}

1. Storchous, I. (2016). The protection of the buckwheat from weeds: domestic and foreign experience. Propozytsia, 14.01.2016 Retrieved from https://propozitsiya.com/ua/zahistgrechki-vid-buryaniv-vitchiznyaniy-ta-zarubizhniy-dosvid [in Ukrainian].

2. National report on the state of the environment in Ukraine in 2011 (2012). Ministry of Ecology and Natural Resources of Ukraine. K.: LAT \& Kyiv [in Ukrainian].

3. Zabkiewicz, J.A. (2000). Adjuvant and herbicidal efficacy - present status and future prospects. Weed Res., 40, No. 1, pp. 139-149.

4. Morderer, Ye.Yu. \& Merezhinsky, Yu.G. (2009). Herbicides. Vol. 1. Mechanisms of action and practice. Kyiv: Logos [in Ukrainian]. 
5. Bunting, J.A., Sprague, Ch.L. \& Riechers, D.E. (2004). Proper adjuvant selection for foramsulfuron activity. Crop Protection, 23, pp. 361-366.

6. Storchous, I. (2014). The use of surfactants: why is it important? Agribusiness today, No. 18 (289), pp. 32-33 [in Ukrainian].

7. Anishin, S. (2016). Modern approaches to increasing the efficiency of plant protection products using innovative adjuvants. Agroscope. Agrarian intelligence technologies, Iss. 2, pp. 33-36.

8. AGNS 1056-X (2019). Retrieved from http://www.adjuvants.com.ua/products/electron-tm/

9. Boydstone, R.A. (1992). Drought stress reduction fluazifop-P activity on green foxtail. Weed Sci., 40, pp. 20-24.

10. Rossi, F.S., Tomaso, J.M. \& Neal, J.C. (1993). Fate of fenoxaprop-ethyl applied to moisture-stressed smooth crabgrass (Digitaria ischaemum L.). Weed Sci., 41, pp. 335340 .

11. Radchenko, M., Sychuk, A. \& Morderer, Ye. (2014). Decrease of the herbicide fenoxaprop phytotoxicity in the drought condition: the role of the antioxidant enzymatic system. Journal of Plant Protection Research, 54, No. 4, pp. 390-394.

12. Semenova, I.N. (2015). Synoptic and climatic conditions of drought formation in Ukraine (Unpublished Doctoral thesis). Odessa State Ecological University, Odessa, Ukraine [in Ukrainian].

13. Sharma, S.D. \& Singh, M. (2000). Optimizing foliar activity of glyphosate on Bidens frondosa and Panicum maximum with different adjuvant types. Weed Research, 40, No. 6, pp. 523-533.

14. Spiridonov, Yu.Ya. \& Nikitin, N.V. (2015).Glyphosate-containing herbicides - features of the technology of their application in the wide practice of crop production. Vestnik zashchity rasteniy, 4 (86), pp. 5-11 [in Russian].

15. Guralchuk, Zh.Z., Sychuk, A.M., Gumenyuk, O.V., Rodzevich, O.P., Grynyuk, S.O. \& Morderer, Ye.Yu. (2017). Efficacy of weed control by different formulations of herbicide glyphosate depending on the quality of water and application of adjuvant companion gold. Fiziol. rast. genet., 2017, 49, No. 6, pp. 513-520 [in Ukranian].

16. Welburn, A.R. (1994). The spectral determination of chlorophylls a and $b$ as well as total carotenoids using various solvents with spectrophotometry of different resolution. J. Plant Physiol., 144, pp. 248-254.

\section{ВИВЧЕННЯ ЕФЕКТИВНОСТІ СУМІСННОГО ЗАСТОСУВАННЯ ГЕРБІЦЦИДЇВ ПОХІંДНИХ АРИЛОКСИФЕНОКСИПРОПІОНОВОЇ КИСЛОТИ $З$ АД'ЮВАНТОМ AGNS 1056-X}

\section{Є.Ю. Мордерер ${ }^{1}$, Ж.З. Гуральчук 1 , О.П. Родзевич1, Л. Новак²}

${ }^{1}$ Їнститут фізіології рослин и генетики Національної академії наук України 03022 Київ, вул. Васильківська, 31/17

e-mail: morderer@ifrg.kiev.ua

${ }^{2}$ Агринова Консалтинг, ТОВ

Єсеніце, За ставом, 683252 42, Чеська Республіка

e-mail: ludek.novak@agrinova.cz

У вегетаційних та польових дослідах досліджували ефективність сумісного застосування ад'юванта AGNS 1056-X з гербіцидними препаратами фюзилад форте та агіл з класу грамініцидів, діючі речовини яких є похідними арилоксифеноксипропіонової кислоти (АОФПК). У вегетаційних дослідах в якості об'єкту використовували рослини пшениці озимої (Triticum aestivum L.) як модель однорічних злакових бур'янів. Для визначення впливу умов вологозабезпечення на фітотоксичну дію грамініцидів у вегетаційному досліді створювали штучну посуху шляхом припинення поливу рослин. У польових дослідах визначали ефективність контролювання окремих видів злакових бур'янів, зокрема мишію сизого (Setaria glauca (L.) Pal. Beauv.) та проса курячого 
(Echinochloa crus-galli (L.) Pal. Beauv.). Для оцінки фітотоксичної дії гербіцидів, або ефективності контролювання певного виду бур'янів, в якості критеріїв використовували пригнічення наростання маси сирої або сухої речовини надземної маси рослин, а в окремих дослідах - сумарний вміст хлорофілу у листках рослин. Проведеними дослідженнями встановлено, що додавання ад’юванту AGNS 1056-X прискорює розвиток фітотоксичної дії грамініцидів фюзилад форте та агіл. Найістотніше прискорення розвитку фітотоксичної дії грамініцидів за рахунок додавання ад'юванту AGNS 1056-Х спостерігалося в умовах посухи, коли злакові бур'яни перебували в стані водного стресу. Хоча в окремих випадках при сумісному застосуванні 3 ад'ювантом AGNS 1056-X ефективність контролювання грамініцидами злакових бур'янів зростала, додавання ад'юванту не гарантує підвищення ефективності захисту. У зв'язку з цим сумісне застосування грамініцидів з ад'ювантом AGNS 1056-X не дає змоги зменшувати норму внесення грамініцидів і для досягнення високої ефективності захисту посівів норму внесення необхідно обирати з урахуванням рівня забур'янення, стану розвитку бур'янів та умов навколишнього середовища.

Ключові слова: гербіциди, грамініциди, ад'юванти, фітотоксична дія, контролювання бур'янів, посуха.

ISSN 2308-7099. Фізіологія рослин і генетика. 2020. T. 52. № 3 